IJTC

Ilomata International Journal of Tax \& Accounting

P-ISSN: 2714-9838; E-ISSN: 2714-9846

Vol. 1 No. 1 October 2019 page:12-17

https://www.ilomata.org/index.php/ijtc

\title{
Analysis of Increase in Non-Taxable Income (NTI) in relation with Implementation of Equality Principles and Taxation Base Principles
}

\author{
Jonrisman Sinaga ${ }^{1}$, Machfud Sidik ${ }^{2}$ \\ ${ }^{12}$ Master of Administration Science, Institute of Social Science and \\ Management STIAMI, Jakarta \\ Correspondence: johnsinaga@yahoo.com
}

Submitted: 6 August 2019.

16 Sept 2019.

Revised: 26 August, Published: 30 October 2019.

\begin{abstract}
This research discussed an increase of non-taxable income that expected to be able to step-up the purchasing power, especially in consumption. Increase on non-taxable income which applies has not reflected the equality principle in taxation like what people feel, where non-taxable income has not touched the sense of equality. It becomes a dilemma to the government for expanding the taxation base by increasing nontaxation income. Increase in non-taxable income can reduce the taxation base. Practice in Simplicity or Easy of Tax Administration concept make the application on equality principle in taxation is not maximal, because non-taxation income equalizes all taxpayers' - rich nor poor, sick nor health, and citizens who are on education. Implementation of this concept is inseparable from taxpayer database condition which based on Identity Number that has not beneficial. Increase of non-taxable income also decreases the Tax Revenue Article 21 where the revenue decreased by $4.65 \%$ in 2016 . Increase in non-taxable income is expected to boost the purchasing power of citizen, hence demand on goods and service will increase. With the increase of demand, production to absorb the employment that becomes the object of Non-Taxable Income Article 21. Keywords : Non-Taxable Income, Implementation on Justice Principles, Principles in Expanding
\end{abstract}

Taxation Base

\section{INTRODUCTION}

Non-Taxable Income that has been set has a value that could not be changed or the value

is considered fixed. Increase in Non-Taxable Income only could be done by the government. From early 1983 to the Adjustment of Non-Taxable Income in 2016, the Limitation to Non-Taxable Income has adjusted with development on the economic world (Saez, Slemrod, \& Giertz, 2012).

Table 1. Increase on Non-Taxable Income (in Rupiah) 
Analysis of Increase in Non-Taxable Income (NTI) in relation with Implementation of Equality Principles and Taxation Base Principles Sinaga, Sidik

\begin{tabular}{|c|c|c|c|c|}
\hline Legal Basis & $\underset{\mathbf{r}}{\text { Taxpaye }}$ & $\begin{array}{c}\text { Addition for } \\
\text { Married } \\
\text { Taxpayer }\end{array}$ & $\begin{array}{l}\text { Addition } \\
\text { for } \\
\text { Depende } \\
\text { nts }\end{array}$ & $\begin{array}{c}\text { Addition if } \\
\text { Wife } \\
\text { Income } \\
\text { Accumulat } \\
\text { ed }\end{array}$ \\
\hline $\begin{array}{lll}\text { Law } & \text { No.8 } & \text { year } \\
1983 & & \end{array}$ & 960.000 & 480.000 & 480.000 & 960.000 \\
\hline $\begin{array}{llll}\text { Law No. } 10 & \text { year } \\
1994 & & & \\
\end{array}$ & $\begin{array}{l}1.728 .00 \\
0\end{array}$ & 864.000 & 864.000 & 1.728 .000 \\
\hline $\begin{array}{lll}\text { Law } & \text { No.17 } & \text { year } \\
2000 & & \end{array}$ & $\begin{array}{l}2.880 .00 \\
0\end{array}$ & 1.440 .000 & 1.440 .000 & 2.880 .000 \\
\hline 564/MoFD.03/2004 & $\begin{array}{l}12.000 .0 \\
00\end{array}$ & 1.200 .000 & 1.200 .000 & 12.000 .000 \\
\hline 137/MoFR.05/2005 & $\begin{array}{l}13.200 .0 \\
00\end{array}$ & 1.200 .000 & 1.200 .000 & 13.200 .000 \\
\hline $\begin{array}{lll}\text { Law } & \text { No.36 } & \text { Year } \\
2008 & & \\
\end{array}$ & $\begin{array}{l}5.840 .00 \\
0\end{array}$ & 5.840 .000 & 5.840 .000 & 5.840 .000 \\
\hline $\begin{array}{l}\text { 162/ } \\
\text { MoFR.011/2012 }\end{array}$ & $\begin{array}{l}24.300 .0 \\
00\end{array}$ & 2.025 .000 & 2.025 .000 & 24.300 .000 \\
\hline $\begin{array}{l}\text { MoFR.010/122/ } \\
2015\end{array}$ & $\begin{array}{l}36.000 .0 \\
00\end{array}$ & 3.600 .000 & 3.600 .000 & 36.000 .000 \\
\hline $\begin{array}{l}\text { No.101/ } \\
\text { MoFR.010.2016 }\end{array}$ & $\begin{array}{l}54.000 .0 \\
00\end{array}$ & 4.500 .000 & 4.500 .000 & 54.000 .000 \\
\hline
\end{tabular}

Source: www.pajak.go.id

Related to government discourse on adjusting the amount of NonTaxable Income (NTI), many parties commented that increase on NTI could make the target of government's tax revenue increment from Income Tax (IT) 21 or employee this year will not be reached. (Pudyatmoko, 2017)

The government changed the limit of Non-Taxable Income with some considerations, i.e: First, to keep citizen's purchasing power. As known in a few years, there are some movements on basic necessities goods. Second, the increase in Non-Taxable Income is one of the tax stimuli that could boost consumption and economic growth. Increase on Non-Taxable income is expected to have a good impact on tax revenue rate. Although there is a decrease in Non-Taxable Income, this new implementation could increase the tax revenue that in micro will be decreased, and an increase in citizen's purchasing power. Non-Taxable Income and layered-tax rate that could be implemented in the taxpayer's taxable income (Nafia \& Sunandar, 2016), (Lewa, Kalangi, \& Pontoh, 2018).

The problem that faces in implementation of Non-Taxable Income, First, Non-Taxable Income equalized the condition of taxpayer except marital status and numbers of dependents. Thus, taxpayers and individuals will face the inequality of non-taxable income which that person gets is the same with non-taxable income that healthy person get. 
Analysis of Increase in Non-Taxable Income (NTI) in relation with Implementation of Equality Principles and Taxation Base Principles Sinaga, Sidik

Second, Non-Taxable Income assumes as if all people do not need education expenses. Taxpayers who professionally work such as programmer, lecturer, accountant, or doctor, that needs further education for upgrading the skill, Third increase in numbers of NonTaxable Income can be done by Minister of Finance Regulation. Means that the amount of Non-Taxable Income always has to be suitable for the condition. Fourth, Non-Taxable Income could not differentiate taxpayers bases on the domicile. The difference in living cost between taxpayers which lives in Jakarta will bear the bigger business cost and make the net income smaller than same taxpayer's business cost in Papua.

According to the Performance Report of Director-General of Tax in 2016, the realization of IT Revenue Article 21 in 2016 is Rp109.153,00 billion (84,39\%). Income Tax Revenue Article 21 in 2016 decreased by $4,65 \%$ compared to 2015, which caused by a decrease in instalment deposit IT article 21. This related to government policy about adjustment of Non-Taxable income amount year 2016 which have an impact in decreasing number of individual employee taxpayers that decreased with IT 21. Policy on increasing the Non-Taxable Income year 2016 is regulated in Minister of Finance Regulation Number 101/PMK 010/ 2016 issued in June 22nd 2016 about The Adjustment for Amount of NonTaxable Income that has been set. Based on this regulation, the Taxpayer's Income Tax for individual increased from $\mathrm{Rp} 36$ million to $\mathrm{Rp}$ 54 million per year.

In counting the amount of Non-Taxable Income, individual taxpayers must reduce the net income with Non-Taxable Income. Basically, to count the amount of tax that must be paid, gross income individual taxpayer could be reduced by the expenses that the person paid to get, charge, and keep the income until the taxpayer gets net income. After that, individual taxpayer can reduce non-taxable income to get taxable income (Weol, Nangoi, \& Wangkar, 2018).

The cause on increase In NTI is increase on Province Minimum Wage. If the increase of PMW is not followed by increase on NTI, the tax which bore by taxpayer will be higher, because the income is higher but there is not any increment in NTI [ CITATION Jen19 V 1057 ]. The evidence shown that elasticity of taxable income related to marginal- tax-rate which at least one or even higher (Feldstein, 1995). Low-level of exclusive income tax buoyancy conclude that enormous taxation reduce added by increasing the limit of taxable income in cross-destination (Bilquees, 2004). In increasing the tax revenue, taxpayers is one of important aspects and the backbone of tax revenue, all taxpayer's activity in running their taxation responsibility has been regulated in General Provision and Taxation Procedures (Susanti \& Andi, 2019).

14 | Ilomata International Journal of Tax \& Accounting

Vol. 1 No. 1 Oct 2019 
Analysis of Increase in Non-Taxable Income (NTI) in relation with Implementation of Equality Principles and Taxation Base Principles Sinaga, Sidik

\section{METHOD}

This research used a qualitative approach, means that gaining as much information from taxation literature (primary data) and informant (secondary data) also field observation for analyzing increase on NonTaxable Income (NTI) in relation with Implementation of Principles of Justice and Principles of Taxation Base Expansion.

Informants were not decided by statistical mathematics but depend on the saturation of data that was obtained like stated by Guba and Lincoln (1985:202) "Informatinal redundance, not a statistical confidence level" Level of answer saturation in this analysis was reached on the sixth informant. Questions in the in-depth interview were submitted to the informant who believed to understand and master the research topic. Guba and Lincoln (1985:199) stated that in a qualitative approach, sampling must be decided before for a certain purpose; sampling purpose, to get the necessary information from the right individual. The informants that have been chosen based on purposive sampling: (1) 3 (three) person from Taxation Academician or Taxation Lecturer; (2) 2 (two) person from taxation practitioner or tax consultant; and (3) 1 (one) person, Director of Potential, Obedience and Tax Revenue Directorate General of Tax.

\section{RESULT AND DISCUSSION}

\section{Non Taxable Income in Implementation of Principles in Tax Equality}

Equality in taxation can be divided into 3 categories. Those are Horizontal equality, vertical, and Special. Horizontal Equality is people who have the same income, will pay an equal amount of tax. Meanwhile, vertical equality is people who have a bigger income should pay a bigger amount of tax. Meanwhile special or zonation equality is one of equality in taxation which applied based on zonation or taxpayer domicile.

In the implementation of the equality principle of taxation must be followed by principles of paying ability. Although there are things about tax collection is arranged by law or have a legal foundation. This has been reflected from the French revolution when one of the causes of the french revolution is discrimination on tax collection. The principle on the ability to pay tax is one of a sensible way to pay public good and service supply such as national defence, health, people's education, and quality of the environment.

In the implementation of the taxation system, Indonesia uses simplicity principle or easy of tax administration, where in implementation of these principles, taxation regulation tends to be 
Analysis of Increase in Non-Taxable Income (NTI) in relation with Implementation of Equality Principles and Taxation Base Principles Sinaga, Sidik

discriminative. The government made all of the tax regulations easy to implement although it becomes unequal.

Increase in Non-Taxable Income by numbers or Non-Taxable Income by regulations or policy has not reflected equality principles. This can be seen by Non-Taxable Income is one for all, meaning that NonTaxable Income for a healthy or sick person is the same. People who undergo education or self-development education has not given an extra allowance, meanwhile, rich people who do not need Non-Income Taxation are given the Non-Taxation Income. Simplicity Concept in implementation of Non-Taxable Income has made the Equality Principle become not maximal in Indonesian Taxation.

\section{Non-Taxation Income (NTI) in Relation with Principles of Taxation Base Expanding}

Increase of Non-Taxation Income certainly decreases Tax Revenue article 21. Like in table 2 which shows that Income Tax Revenue from 2013 to 2015 had increased, and in 2015 had decreased. On 2014 increased by $17.15 \%$, in 2015 increased by $8.52 \%$, and in 2016 decreased by $4.78 \%$. this decrease caused by increase on non-taxable income from Rp36,000,000 to Rp54,000,000. So does in IT article 25/29 undergo the same thing, in 2016 decreased by $36.12 \%$.

Table 2. Ratio of Realization in Domestic Tax Revenue Non-oil and gas and VAT

2013-2016 (in billion Rupiah)

\begin{tabular}{|c|c|c|c|c|c|c|c|c|}
\hline $\mathbf{N}$ & Tax Revenue & 2016 & $(+/-)$ & 2015 & $(+/-)$ & 2014 & $(+/-)$ & 2013 \\
\hline 1 & IT Article 21 & 109.1 & - & 114.6 & $8,52 \%$ & 105.6 & 17,15 & 90.16 \\
\hline & & 53 & $4,77 \%$ & 25 & & 25 & & \\
\hline 2 & $\begin{array}{l}\text { IT Article 25/29 } \\
\text { OP }\end{array}$ & 5.275 & $\begin{array}{l}- \\
36,12 \\
\%\end{array}$ & 8.258 & $\begin{array}{l}75,55 \\
\%\end{array}$ & 4.704 & $7,32 \%$ & 4.383 \\
\hline 3 & Domestic IT & $\begin{array}{l}273.4 \\
67\end{array}$ & $-\overline{2,34 \%}$ & $\begin{array}{l}280.0 \\
09\end{array}$ & $\begin{array}{l}16,29 \\
\%\end{array}$ & $\begin{array}{l}240.7 \\
86\end{array}$ & $6,18 \%$ & $\begin{array}{l}226.7 \\
64\end{array}$ \\
\hline
\end{tabular}

Source: Researcher's result, 2018

From descriptions in this discussion, thus this result can be pictured like this:

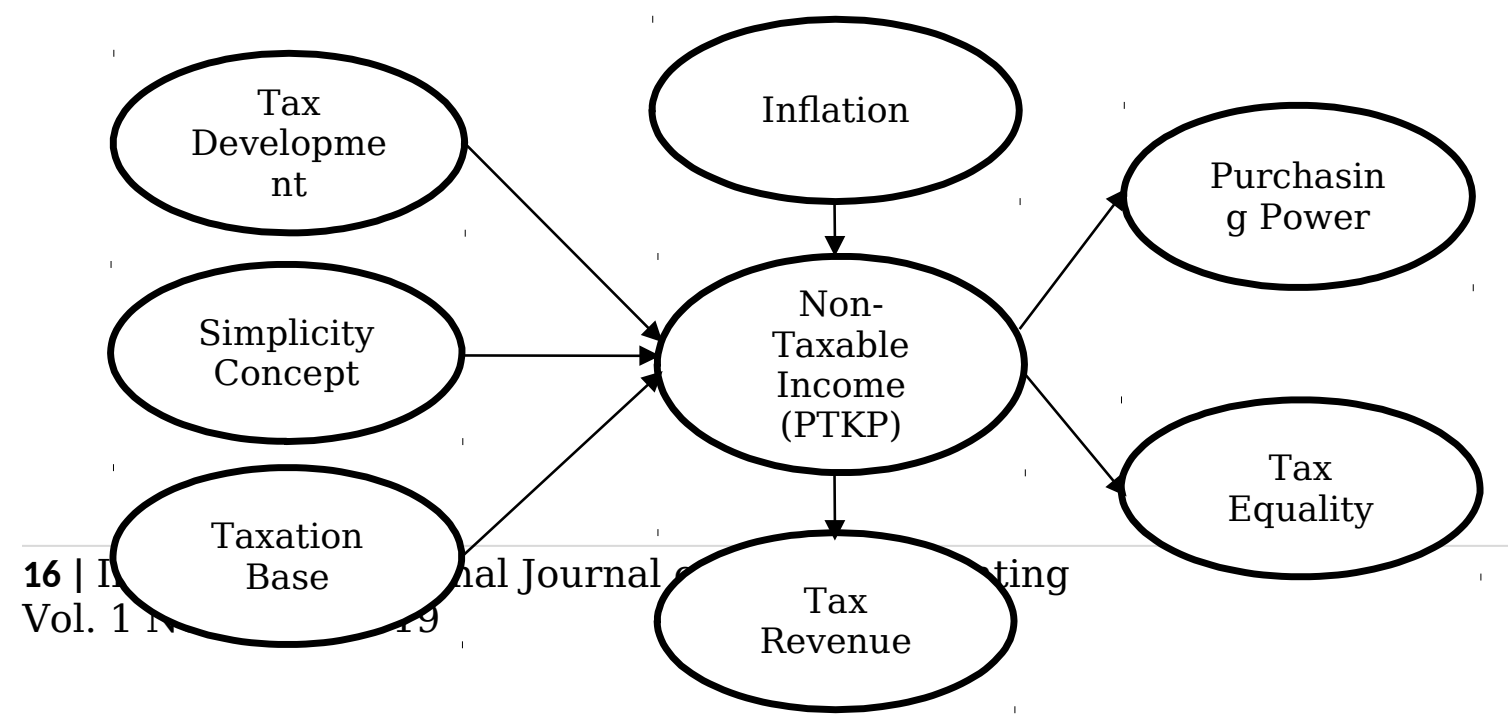


Analysis of Increase in Non-Taxable Income (NTI) in relation with Implementation of Equality Principles and Taxation Base Principles Sinaga, Sidik

\section{Picture 1. Result Model}

From the result of the model picture, described that there is a new entity that researchers have to put inside because this new entity strongly influenced the final result from answering these research question. This new entity is implementation on Simplicity Concept in Indonesia Taxation Practice. This concept becomes a little contradictory with tax equality concept, where simplicity concept emphasized on giving the same Non-Taxable Income facility to all taxpayers, besides status and dependents. Meanwhile, according to Tjahjono Hussen, the same tax collection is a discriminative action towards taxpayers.

\section{CONCLUSION}

Increase on Non-Taxable Income has not reflected the Implementation of Tax Equality. Indonesia uses Simplicity concept of Ease of Tax Administration. The Simplicity concept, based on the first and sixth informant, is not fair. Equality and Simplicity Concept is toilsome to do simultaneously, because, in this case, DGT has not had a good and competent taxpayer database to back up the implementation of Equality Principle in Increasing The Non-Taxation Income. Considering the awful taxpayer's database comes from DGT side, then Ease of Tax Administration Concept or Simplicity Concept is the most rational concept in implementation of Equality Principle because a tax regulation cannot be or hard to fulfil the public satisfactory element. In the future, if taxpayer database has become better-status, dependent, education, and health, can be detected from the database, the equality concept of equality in taxation especially in the implementation of the increase in Non-Taxation Income can be implemented. Meaning that implementation of the value of types of reducing items in Non-Taxable Income can be customized with the necessities and condition of taxpayers.

Increase of Non-Taxation Income is expected to boost people's purchasing power to consume Taxable Goods with the hope that other taxation base like Value-Added Tax (VAT) could help in taxation income. Implementation on Non-Income Tax or Tax Allowance supposed to be more precise to people who need. Meanwhile, people that do not need Non-Taxable Income should not get the tax allowance, thus people who do not need non-taxable income can contribute more in development where this thing could be energy boost for DGT in extended taxation base concept (Isnawati, Hilendri, Isnaini, \& Jumaidi, 2018). 
Analysis of Increase in Non-Taxable Income (NTI) in relation with Implementation of Equality Principles and Taxation Base Principles Sinaga, Sidik

As a part from researchers' responsibility in conducting scientific research in this thesis, suggestions and recommendation that concluded are: Government, in this case, Directorate General of Tax, is suggested to fix the regulations, especially in Personal Allowance or Non-Taxable Income from Simplicity Concept to Complexity Concept to fulfil the element of Equality Principle. For Institution of Directorate General of Tax should always upgrade the taxpayer database system and taxation database itself. The government is also suggested to dig other taxation bases through taxation socialization to areas that have been touched in terms of implementation of Income Tax, or government, in this case, to agency or government department to keep an eye of taxation base probability in case of Non-Tax State Collection.

\section{REFERENCES}

Bilquees, F. (2004). Elasticity and Buoyancy of the Tax System in Pakistan. The Pakistan Development Review, 43(1), 73-93. https://doi.org/10.30541/v43i1pp.73-93

Feldstein, M. (1995). The Effect of Marginal Tax Rates on Taxable Income: A Panel Study of the 1986 Tax Reform Act. Journal of Political Economy, 103(3), 551-572. https://doi.org/10.1086/261994

Isnawati, I., Hilendri, B. A., Isnaini, Z., \& Jumaidi, L. T. (2018). Analisis Kehilangan Penerimaan Negara Di Sektor Pajak Sebagai Konsekuensi Dari Pengukuhan Besaran Kenaikan PTKP (Studi Kasus Pada Dirjen Pajak Nusa Tenggara). Jurnal Aplikasi Akuntansi, 2(2), 076-101. https://doi.org/10.29303/jaa.v2i2.24

Jeniliasari, D., Susyanti, J., \& Wahono, B. (2019). Analisis Perbandingan Penerimaan Pajak Penghasilan (PPh) Wajib Pajak Orang Pribadi Sebelum dan Sesudah Kenaikan Penghasilan Tidak Kena Pajak Pada Kantor Pelayanan Pajak (KPP) Pratama Malang Selatan. e-Jurnal Riset Manajemen, 8(8), 40-53. Retrieved from http://riset.unisma.ac.id/index.php/jrm/article/view/4108/3585

Lewa, M., Kalangi, L., \& Pontoh, W. (2018). Analisis Perubahan Tarif Penghasilan Tidak Kena Pajak (PTKP) Tahun 2015 dan Tahun 2016 Terhadap Penerimaan Pajak Penghasilan (PPH) Pasal 21 di Kantor Pelayanan Pajak Pratama Bitung. GOING CONCERN : JURNAL RISET AKUNTANSI, $13(04)$,

244-253. https://doi.org/10.32400/gc.13.03.20120.2018

Nafia, D., \& Sunandar. (2016). Analisis Perbedaan Penerimaan Pajak Penghasilan Sebelum Dan Sesudah Kenaikan Penghasilantidak Kena Pajak (PTKP) Pada Kantor Pelayanan Pajak Pratama Tegal. SENIT 2016 (pp. 170-174). Tegal: Politeknik Harapan Bersama. Retrieved from https://ejournal.poltektegal.ac.id/index.php/prosiding/article/view/ 
Analysis of Increase in Non-Taxable Income (NTI) in relation with Implementation of Equality Principles and Taxation Base Principles Sinaga, Sidik $375 / 359$

Pudyatmoko, Y. S. (2017). Pengaturan Batas Penghasilan Tidak Kena Pajak Bagi Anak Antara Keadilan Distributif Dan Pelindungan Anak (Studi Terhadap Pandangan Mahasiswa Fakultas Hukum UAJY). Justitia et Pax, 31(2), 57-85. https://doi.org/10.24002/jep.v31i2.1344

Saez, E., Slemrod, J., \& Giertz, S. H. (2012). The Elasticity of Taxable Income with Respect to Marginal Tax Rates: A Critical Review. Journal of Economic Literature, 50(1), 3-50. https://doi.org/10.1257/jel.50.1.3

Susanti, N., \& Andi. (2019). Pengaruh Kenaikan Penghasilan Tidak Kena Pajak (PTKP) Dan Jumlah Wajib Pajak Efektif Terhadap Penerimaan $\mathrm{PPh}$ Pasal 21. JRB-Jurnal Riset Bisnis, 2(1), 32-49. https://doi.org/10.35592/jrb.v2i1.255

Weol, S. C., Nangoi, G. B., \& Wangkar, A. (2018). Analisis Efektivitas Dampak Peningkatan Jumlah Besaran Penghasilan Tidak Kena Pajak Terhadap Penerimaan Pajak Penghasilan Orang Pribadi Pada KPP Pratama Manado. GOING CONCERN : JURNAL RISET AKUNTANSI, 13(04), 365-372. https://doi.org/10.32400/gc.13.03.20273.2018 